of individual birds-their actual routes of travel, their retreat during our winter, and their home in our spring and summer-is adopted, there appears little hope of our ignorance of the mystery of migration being quickly or greatly dissipated. We suggest this subject for consideration at the approaching International Ornithological Congress in Berlin.

(3) The "Catalogue of Canadian Birds," by the Macouns, father and son, is an endeavour, successfully carried out, "to bring together facts on the range and nesting habits of all birds known to reside in, migrate to or visit the northern part of the continent," including Newfoundland, Greenland, and Alaska. The authors enumerate 768 species as the avifauna of the region indicated. There is a tull account of the distribution, nesting habits, and migration of each species, with many interesting notes on their habits and life-history. An introductory note by the director states that the present volume is an enlarged and to a great extent re-written edition of a previous catalogue, in three parts, which became exhausted immediately after publication. This is excellent evidence, not only of the interest taken by the public in the birds of their own country, but of the value to ornithologists generally of the work, for which we have nothing but commendation-except to say that it deserves a better binding-and to express the hope that the same fortune may be in store for the present edition which attended its predecessor.

(4 and 5) These two volumes belong to the series of publications being issued by the Field Museum of Natural History in Chicago. Both are by Mr. C. B. Cory, the curator of the Department of Zoology. The first of these, on "The Birds of the Leeward Islands," enumerates all the species inhabiting Aruba, Curacoa, Bonaire, Islas de Aves, Los Roques, Orchilla, Tortuga, Blanquilla, Los Hermanos, the Testigos, and Margarita. The collections were chiefly made by $\mathrm{Mr}$. J. F. Ferry and Dr. N. Dearborn. Each island is dealt with separately, the list of birds from each being prefaced by a short account of the island and a list of its ornithological literature. Dr. Hartert, now of Tring, had previously visited the larger islands of the group, and has described in detail their avifauna in the Hon. Walter Rothschild's Novitates Zoologicae, and in the Ibis, so that in few of them were there many novelties to be expected. Nevertheless, five new species and three new subspecies were discovered, chiefly on the smaller islets which Mr. Cory's energetic collectors were the first to visit.

Mr. Cory's second book is a much more pretentious volume, and includes, "as far as known, all species and subspecies of birds that occur in Illinois and Wisconsin," the total number being 365 (not 398 , as stated in the preface), with descriptions of their various plumages, nests, and eggs, and geographical distribution, together with more or less brief biographical notes concerning them. It is more, however, than an avifauna; it is, in addition, an ornithology for less advanced students. The book is divided into two parts, the first devoted to a key to the families and species, and the second to biographical notes on the species. No fewer than 274 pages are given to the key, which is constructed on a series of highly artificial characters. In the first place, the birds are divided into two great divisions-water birds and land birds. In the former, Mr. Cory includes landrails, herons, golden plovers, and peewits (because they may sometimes be found feeding near water!); yet ospreys, sea-eagles, and kingfishers, which find their food chiefly in that element, are classed as land birds. The collector with a bird in his hand must first decide whether it is a land or a water species, and, having determined this (not, per- haps, as Mr. Cory would), he must, in order to run down the family, enter tables prepared for him according to the length of the wing. "A large series of specimens has shown," says Mr. Cory, "that while adult birds of the same species differ considerably in length, the wing measure is very constant." Recent investigations have, however, showed this statement to be far from true. Wings vary greatly, not only in actual length in different individuals of the same species, but the wing feathers, the primaries, for instance, vary in length in different proportions. Even Mr. Cory's tables show this. The species Passerherbulus (!) caudacutus nelsoni is to be found in a group with wings from $I^{\circ} 75^{-2} 5$ inches; also in a second, with wings from $2^{\circ} 5^{-2} \cdot 37$ inches long, as well as in a third, with wings from $237^{-2} 75$ inches! Examples of the same sort are numerous. Another species appears in one group as having "belly clear yellow"; in a second with "underfronts yellow or greenish yellow," and in a third with "under-parts pale greenish yellow."

A curious error occurs on p. II4, where an illustration entitled "first five primaries emarginate: Baid eagle," is drawn with six primaries! The author here adheres also to a method of enumerating the primary quills which has long been given up by all modern ornithologists, who number these feathers from the carpal-joint outwards, and not from the point of the wing inwards.

The second and really valuable portion of the work deals with the history of the 365 species found in the two States, in which the very numerous (and excellent, be it said) illustrations appearing in the key are all needlessly repeated, thus adding greatly to the cost and to the bulk of the book. The volume is beautifully printed on a fine-surfaced paper, and is worthy of a better binding than the flimsy paper covers in which it is issued; but it would be greatly improved by having the system of keys to the families and species remodelled and much condensed.

\section{PORTUGUESE ZAMBEZIA.}

F OR the pictures alone this book is worth purchasing. We have rarely seen in any similar work dealing with Africa a better collection of admirable photographs which are apt illustrations of the text. The book is not written round the illustrations, nor are these photographs stuck into the work without relation to its text and purport. If $\mathrm{Mr}$. Maugham had further confined himself in his text to his own personal observations of this relatively vast region of Portuguese Zambezia, and to his own theories based on his personal observations and experience, there would be nothing in the book to criticise unfavourably. But he has conceived it necessary to borrow largely from the works of other writers, borrowings which he frankly acknowledges in the preface, but which, one might plead, were quite unnecessary to his purpose in view.

Somehow or other, a mischievous idea has spread amongst many writers on Africa of late years that it is not sufficient for them to relate their own experiences and to describe a portion of the country they have visited, but that their work must make an attempt at being encyclopædic. If they write as historians of their own personal researches, then they feel obliged to give summaries of linguistics, natural history in general, or botany, which they extract from already published works, and again set forth either

l "Zambezia : a General Description of the Valley of the Zambezi River, from its Delta to the River Aroangwa, with its History, Agricukure, Flora, Fauna, and Ethnography." By R. C. F. Maugham. Pp. xiv+408; with maps and illustrations. (London: John Murray, Igro.) Price 15 s. net. 
as due to their own original research, or, quite fairly (as does Mr. Maugham), as the work and conclusions of other people. But in this transposition, not having sufficient technical knowledge, perhaps, they allow themselves or their printers to mar these summaries with ridiculous mistakes in names, English or Latin, or they repeat the few errors of the persons from whom they borrow. Mr. Maugham does more. He adds a little acid to his work by recounting the theories of his predecessors or fellow-travellers (and very often misinterpreting them in the repetition) and then holding them up to ridicule; while at the same time it is patent to a specialist that he has not taken the trouble to understand what appears to him absurd. I pointed out the same tendency in an earlier work of his, in which he chose-one does not know whyto ridicule theories of the origin of the Bantu languages set forth by English and German philologists, while by his own confession (and certainly by the evidence in his text) he was without special $\mathrm{k}$ n o w ledge of the subject.

If it were not for this desire on his part to have a dig at all and sundry who have at one time or another written on the countries of SouthEast Africa, he would have given us a most agreeable, as well as a most interesting. book; for when he confines himself to his own researches and observations he arouses the interest of $t h \mathrm{e}$ reader and secures the adhesion and respect of those who know Africa as well as he does, or even better. The reader's attention should be directed to the

author's sensible remarks on pp. $157-9$, as to the proportions of the European hold over the southern half of Africa. These should be a corrective to any excessive exultation. In several directions also he renders service to the very few persons in the United Kingdom, and to the three or four individuals in the southern half of Africa, who are foolish enough to care for the preservation of big game and of interesting birds and beasts. $\mathrm{He}$ points out with absolute truth the nonsense of the theory that connects the spread of the Glossina tsetseflies with the abundance of big game: the theory which is quoted by the officers of the British South Africa Companv, and of other great companies controlling South Central Africa, and by the thousands of "sportsmen" now swarming over Africa and slaying everything right and left, as their justification for spurning game regulations and mocking at the attempts of a few "fanatics" who think that at any rate a selection of the big and interesting wild beasts might be preserved for the intelligent appreciation of later generations. He cites this example of the falsity of the theory. ${ }^{1}$ There is a considerable region of desolate country lying between the west bank of the Shiré River and the north bank of the Zambezi up to the vicinity of Tete. In this district, across which passes the Cape-to-Cairo telegraph line, there are few human inhabitants, and there is absolutely no wild game. Yet here the tsetse swarms, as it does, possibly, nowhere else in Africa; in fact, its extraordinary abundance has driven away most of the human inhabitants because they have found it impossible to keep any form of domestic animal. Now, if this district swarmed with game, one would be justified in supposing that by destroying the game one might drive away the tsetse. But apparently the Glossina flies have made life unbearable for all creatures that do not fly or burrow in the ground, and yet they continue to swarm.

Mr. Maugham, however, is not always consistent

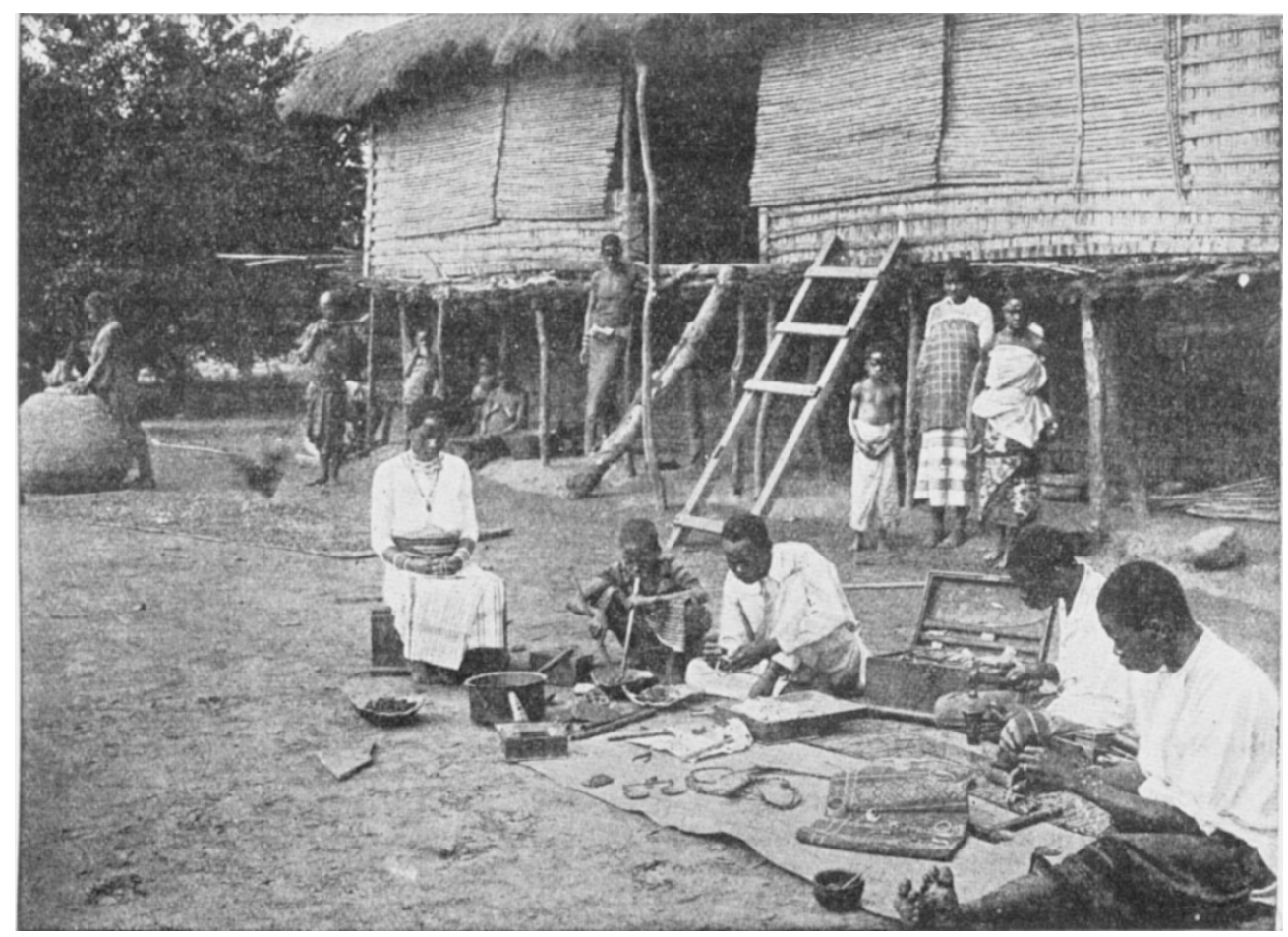

and Huts built upon Piles. From "Zambezia."

in his desire to create a little tolerance for the existence of beasts and birds, not as yet of interest to South African settlers or sportsmen. He says contemptuously that "the rhinoceros will have to go," but gives no justification for such an utterance. To the intellectual interests of the world the two forms of existing African rhinoceros are quite as important as (let us say) the moderate prosperity of a few European settlers.

But, of course, the only proper solution of this question in Zambezia, as well as elsewhere, is the marking off of game preserves which shall grow by degrees into national parks, and shall harbour and sustain the wild fauna. In the intervening regions the land must be given up to exploitation by man, black or white, and any game straying beyond the reserves should receive no protection. But, of course, the

1 Further support is given to his remarks in the very interesting article on the flora and fauna of Ngamiland (by Major Lugard) just published in the Kew Bulletin ard deserving special notice. 
farce of the "reserve" system at present is, first, that the local white and black population do not obey the law, and the local authorities seldom enforce it, and second, that the Government is somewhat too ready to set aside the law in favour of distinguished sportsmen.

In no book which the reviewer has yet seen have the great beasts, the landscapes, and the people been more admirably photographed than in this work on Zambezia, while at the same time due justice is done to the Portuguese towns, the Portuguese officials, and generally to such civilisation as Portugal has been ab'e to introduce into these lands.

\section{H. H. JOHNSTON.}

\section{PELLAGRA AND ITS CAUSE.}

A GOOD deal of notice has been taken lately in medical journals and in the newspapers of the disease pellagra. It is difficult for British folk to realise the scourge this disease causes in many countries, but chiefly in Italy, Roumania, Spain, Tyrol, and other countries in south-eastern Europe. In the United States of America, pellagra has spread recently to an alarming extent, and in several British colonies and protectorates, markedly the West Indies and Egypt, pellagra is a serious ailment. Persons who contract the disease present a train of symptoms which may be summarised as follows :- "sunburning " of face, neck, chest, and hands is an early and very prevalent manifestation; stomachic and intestinal catarrh; feverishness; skin rash; lassitude and weakness. Spring and autumn recurrences continuing for years further tend to mental excitement and bodily weakness, leading all too frequently to lunacy and a fatal issue.

The disease has hitherto been attributed to eating damaged maize, which is so largely consumed as "polenta," the "porridge" of Italy. In the United States maize is termed Indian corn, and under various names it is used in many countries. In I905 Dr. L. W. Sambon, at a meeting of the Tropical Section of the British Medical Association, criticised the accepted theory, pointing out that pellagra did not seem to be a food disease or due in any way to unsound maize, but that in all probability it was due to a parasite-a protozoon. Dr. Sambon supported his theory by arguments based upon the well-established priniciples applicable to protozoal infections, and put in a form which appealed to men of science. His theory gained adherents until it gradually came to be considered a duty to humanity and to science that the question should be fully inquired into. With this object in view, a Pellagra Investigation Committee was formed in London by Mr. James Cantlie, and Dr. Sambon was sent to Italy on March 20, I9Io.

At present the field commission in Italy, consisting of Dr. Sambon and his assistants, is engaged in inquiring into the epidemiology of pellagra. Many pellagrous districts in northern Italy have been visited and the banks of the streams searched for possible carriers of the disease. The field commission has come to the conclusion that pellagra occurs amongst the cultivators and not amongst the consumers of maize; that it is the agricultural labourer, not the town dweller, who suffers from pellagra, and that it is whilst working in the field that the labourer becomes infected. In a telegram dated Rome, May I3, and published in the Times, May 14, Dr. Sambon states that it "has been definitely proved that maize is not the cause of pellagra." In addition the telegram assures us that "the parasitic conveyer is the Simulium reptans." NO. 2 I I7, VOL. 83$]$
The Simulium is a species of fly commonly called a "sandfly"; its larvæ are met with on the rocks and stones along the streams in pellagrous countries, and Dr. Sambon seems to connect this fly with the spread of pellagra.

So far as we know, Dr. Sambon has not found the parasite, nor is there direct proof that the Simulium is the actual carrier. That he has found cause for the statement that eating maize is not the cause of this disease is highly probable, for several men of science, such as Babes (Roumania) and Alessandrini (Rome), have declared in favour of Sambon's theory, and have been working on the lines suggested by him for the elucidation of pellagra. Even with the announcement above quoted, stating what work has been done, there is much yet to do. Questions of the kind are not settled in a day, and it may take years of inquiry before we have finally settled what Dr. Sambon has so well begun.

The fact that it is a duty to humanity and to science that pellagra should be investigated does not provide the necessary money, and the committee in London has endeavoured to keep the inquiry going by appealing to friends to help. So far some $245 l$. have been actually collected, and further sums have been guaranteed; but even should the Government favour the work by contributing the ${ }_{1} 50 l$. which the committee was led to believe might be the case, the sum is quite inadequate, and unless further donations are speedily to hand the field commission must be recalled from Italy in a fortnight. Sir Lauder Brunton, Bart., is the chairman of the committee; Prof. F. M. Sandwith vice-chairman; the bankers are the London and South-Western Bank, Great Portland Street branch; and donations may be sent to the treasurer, Dr. Clement Godson, 82 Brook Street, $\mathrm{W}_{\text {., }}$ or to $\mathrm{Mr}$. James Cantlie, I40 Harley Street, London, W., honorary secretary, Pellagra Investigation Committee.

\section{NOTES.}

FOR some time past a scheme for the distribution of time signals by wireless telegraphy has been mooted with the view of assisting navigation and for the determination of longitude. The Eiffel Tower in Paris and the summit of Teneriffe have been proposed as suitable sites for the emission of these signais, and we now learn that the plan for which M. Bouquet de la Grye and Commandant Guyou are more especially responsible is so far complete that the first signals were dispatched from the former station at midnight on May 23. The Paris correspondent of the Morning Post states that Paris time was transmitted from the observatory by way of the Eiffel Tower by wireless telegraphy to all wireless stations and ships fitted with wireless apparatus within a radius of between 2500 and 3000 miles. The system is an automatic one, and a Morse sign is sent into space first at midnight, again two minutes after midnight, and, finally, four minutes after midnight. Thus, steamers furnished with wireless telegraphic apparatus will no doubt be placed in a more favourable position, but the suggestion that has been made in some quarters, that chronometers can be dispensed with, seems premature. The receipt of a signal will not enable a ship to determine its position or even its longitude. All it will do is to give the error of the chronometer. The ship's officers will not be able to forgo the use of Sumner lines and other devices, and for these the knowledge of local time and the use of a ship's chronometers will be convenient. It may be desirable to point out here what is the kind of error in longitude to which in these days of accurate navigation a ship is liable, or what is the 